\title{
Efficacy of preoperative nonsteroidal anti-inflammatory drug and the re-dilation technique in minimizing miosis after femtosecond laser in cataract surgery
}

\section{Eficácia do AINE pré-operatório e da técnica de re-dilatação em minimizar a miose na cirurgia de catarata com laser de femtosegundo}

\author{
Bruna Vieira Ventura1,2, Laura Portela Rabello', Fernanda Silvestre', Marcelo Carvalho Ventura',2 \\ 1. Fundação Altino Ventura, Recife, PE, Brazil. \\ 2. HOPE Hospital de Olhos, Recife, PE, Brazil.
}

\begin{abstract}
Purpose: To assess the efficacy of using a nonsteroidal anti-inflammatory drug preoperatively and of applying the re-dilation technique when necessary to minimize pupil size variation when comparing the degree of mydriasis before femtosecond laser pretreatment with that at the beginning of phacoemulsification. Methods: This retrospective study included patients who underwent cataract surgery using the LenSx (Alcon Laboratories, Inc., Fort Worth, TX). Our routine dilating regimen with flurbiprofen, tropicamide, and phenylephrine was used. The re-dilation technique was applied on eyes that manifested with a pupillary diameter that was smaller than the programmed capsulotomy diameter after laser pretreatment. The technique consists of overcoming pupillary contraction by instilling tropicamide and phenylephrine before phacoemulsification. Pupil size was assessed before femtosecond laser application and at the beginning of phacoemulsification. Results: Seventy-five eyes (70 patients) were included. Nine (12\%) eyes underwent the re-dilation technique. There was no significant difference in mean pupillary diameter and mean pupillary area between the two studied surgical time points ( $p=0.412$ and 0.437 , respectively). The overall pupillary area constriction was $2.4 \mathrm{~mm}^{2}$. Immediately before opening the wounds for phacoemulsification, none of the eyes presented with a pupillary diameter $<5 \mathrm{~mm}$, and 61 (85.3\%) eyes had a pupillary diameter $>6 \mathrm{~mm}$. Conclusion: Preoperative administration of nonsteroidal anti-inflammatory drug and the re-dilation technique resulted in no significant pupil
\end{abstract}

Submitted for publication: October 10, 2017

Accepted for publication: July 24, 2018

Funding: No specific financial support was available for this study.

Disclosure of potential conflicts of interest: None of the authors have any potential conflicts of interest to disclose.

Corresponding author: Bruna V. Ventura.

Fundação Altino Ventura - FAV - Rua do Progresso, 71 - Recife, PE - 50070-020 Brazil - E-mail: brunaventuramd@gmail.com

Approved by the following research ethics committee: Fundação Altino Ventura (\# 47333115.9.0000.5532). size variation in eyes that were pretreated with the femtosecond laser, when comparing the measurements made before the laser application and at the beginning of phacoemulsification. This approach can avoid the need to proceed with cataract extraction with a constricted pupil.

Keywords: Cataract extraction; Preoperative period; Laser therapy; Intraoperative complications; Miosis; Nonsteroidal anti-inflammatory drugs

RESUMO | Objetivo: Avaliar a eficácia do uso de anti-inflamatório não-esteróide no pré-operatório e aplicação da técnica de re-dilatação quando necessária para minimizar a variação do tamanho pupilar ao comparar o grau de midríase antes do tratamento com laser de femtosegundo no início da facoemulsificação. Métodos: Esse estudo retrospectivo incluiu pacientes que foram submetidos à cirurgia de catarata usando o LenSx (Alcon Laboratories, Inc., Fort Worth, TX). Nosso regime de dilatação de rotina com flurbiprofeno, tropicamida e fenilefrina foi usado. A técnica de re-dilatação doi aplicada em olhos que se manifestaram com um diâmetro pupilar menor do que o diâmetro da capsulotomia programado após o pré-tratamento a laser. A técnica consiste em superar a contração pupilar pela instilação de tropicamida e fenilefrina antes da facoemulsificação. O tamanho pupilar foi avaliado antes da aplicação do laser de femtosegundo e no inicio da facoemulsificação. Resultados: Setenta e cinco olhos (70 pacientes) foram incluídos. Nove (12\%) olhos foram submetidos à técnica de re-dilatação. Não houve diferença significativa no diâmetro pupilar médio e na área pupilar média entre os dois tempos cirúrgicos estudados $(p=0,412$ e 0,437 , respectivamente). A constrição global da área pupilar foi de $2,4 \mathrm{~mm}^{2}$. Imediatamente antes de abrir as incisões para a facoemulsificação, nenhum dos olhos apresentava diâmetro pupilar <5 mm e 61 (85,3\%) olhos apresentavam um diâmetro pupilar $>6 \mathrm{~mm}$. Conclusões: $\mathrm{O}$ administração pré-operatória de anti-inflamatório não-esteróide e da técnica de re-dilatação resultaram em uma variação significativa do tamanho pupilar em olhos que foram pré-tratados com laser de femtosegundo, 
comparando as medidas realizadas antes da aplicação do laser e no inicio da facoemulsificação. Essa abordagem pode evitar a necessidade de prosseguir com a extração da catarata com uma pupila contraída.

Descritores: Extração de catarata; Período pré-operatório; Terapia a laser; Complicações intraoperatórias; Miose; Anti-inflamatórios não esteroides

\section{INTRODUCTION}

Femtosecond laser in cataract surgery is useful for both routine and challenging cases ${ }^{(1-3)}$. However, its use is not exempt from adverse events, such as induction of significant miosis ${ }^{(4-8)}$. In fact, previous studies reported pupil size reduction after laser pretreatment in up to $32 \%$ of cases $^{(4)}$. Given the increased risk of surgical complications ${ }^{(9)}$, preventing miosis is an important issue among cataract surgeons.

Diakonis et al. ${ }^{(7)}$ compared three laser platforms with regard to pupil size alteration in femtosecond laser-assisted cataract surgery (FLACS). They found that the LenSx (Alcon Laboratories, Inc., Fort Worth, TX); the Catalys Precision Laser System (OptiMedica, Abbott Medical Optics, Santa Ana, CA); and the Victus (Bausch \& Lomb, Inc., Rochester, NY) significantly decreased the pupillary diameter, with the LenSx inducing the highest degree of miosis, followed by the Catalys and, finally, the Victus. Another study reported a $29.7 \%$ decrease in pupillary area after laser pretreatment using the Catalys Precision Laser System ${ }^{(8)}$. Notably, the preoperative dilating regimen used in the previous studies did not include a nonsteroidal anti-inflammatory drug (NSAID). Moreover, the degree of miosis correlated with age, time for lens fragmentation, and time for the creation of the main incision.

NSAIDs inhibit the synthesis of prostaglandin, which is an intraocular mediator of inflammation ${ }^{(10)}$. Higher levels of prostaglandin are seen during FLACS than during conventional surgery, and studies have suggested their important role in the increased risk of intraoperative miosis after femtosecond laser use ${ }^{(11-15)}$. NSAIDs are effective in lowering these prostaglandin levels $s^{(13,14)}$ and have the potential benefit of decreasing intraoperative pupillary contraction during FLACS ${ }^{(15)}$. Aside from the use of NSAIDs, a greater surgeon experience and the improvement in laser software have decreased the occurrence of miosis after femtosecond laser application ${ }^{(5)}$. However, despite all efforts, some cases still develop a small pupil before cataract extraction ${ }^{(7)}$. We recently described re-dilation as a technique to manage significant miosis caused by the femtosecond laser in some eyes ${ }^{(16)}$. This technique consists of overcoming pupillary contraction with the use of more dilating drops before proceeding with phacoemulsification.

Since there is a lack of knowledge regarding the effectiveness of using preoperative NSAID combined with the re-dilation technique, when necessary, the aim of the present study was to assess the efficacy of this approach to minimize pupil size variation by comparing the degree of mydriasis before femtosecond laser pretreatment with that at the beginning of phacoemulsification.

\section{METHODS}

This retrospective study was approved by the institutional review board of the Altino Ventura Foundation, in Recife, Brazil and followed the tenets of the Declaration of Helsinki. All patients who underwent cataract surgery by two surgeons (MCV and BVV) who used the LenSx at the HOPE Eye Hospital, in Recife, Brazil between March 2015 and October 2015 were eligible for inclusion. All femtosecond laser pretreatments were done by a single doctor (BVV) who had extensive experience on surgeries using the LenSx, whereas the phacoemulsification was done by either one of the two surgeons (MCV and BVV). Patients who received topical treatment for glaucoma or any other disease and those with inflammatory eye disease, previous ocular surgery or trauma, pseudoexfoliation syndrome, preoperative zonular weakness, history of treatment with an alpha-adrenergic antagonist, history of poor pupillary dilation $(<5 \mathrm{~mm})$, or rheumatologic disease were excluded from the study. At our institution, patients for surgery are randomly assigned in one of two rooms, one of which has a video recording system. Therefore, we excluded cases that did not have surgical videos of both the femtosecond laser pretreatment and phacoemulsification.

The patient's charts were reviewed to collect information on age, gender, hypertension status, diabetes mellitus history, preoperative intraocular pressure (IOP), endothelial cell count, and central corneal thickness. In addition, we took note of the laser parameters, such as energy used to create the capsulotomy and lens fragmentation; crystalline lens thickness measured intraoperatively by the spectral domain optical coherence tomographer (OCT) of the LenSx; the distance measured by the OCT as the delta up and delta down, which corresponds to the cylindrical area where the laser is fired to perform the 
capsulotomy; whereas an arcuate incision was performed; and the total suction-on time. The total suction-on time was defined as the time period between turning on and off suction in the patient interface. Given that the LenSx did not automatically register this parameter, the videos from the LenSx treatment were reviewed and the suction-on time was measured manually and recorded to one decimal place of a second.

\section{Surgical technique}

Our routine pupil-dilating regimen was used in all cases and consisted of administration of $1 \%$ tropicamide (Mydriacyl, Alcon Lab. Inc., Fort Worth, TX) and 10\% phenylephrine (Fenilefrina, Allergan, Irvine, CA) four times one hour before the surgery and once between the laser application and the phacoemulsification. In addition, a drop of $0.03 \%$ flurbiprofen (Ocufen, Allergan) was instilled once an hour before the surgery. All procedures were performed under topical anesthesia using $0.5 \%$ proxymetacaine chloride (Anestalcon, Alcon Lab.).

The femtosecond laser-assisted pretreatment included main corneal incision, side port corneal incision, capsulotomy, and lens fragmentation. Depending on the preoperative corneal astigmatism, an arcuate incision was also made. The energy used to perform the main incision and the side port incision was $5 \mu$. The energy used to make the capsulotomy varied from 6.00 to $7.50 \mu$ ), with $0.5-\mu \mathrm{J}$ intervals, and was adjusted during surgery with the objective of avoiding incomplete capsulotomies. The delta up and delta down were preset to $275 \mu \mathrm{m}$ and $350 \mu \mathrm{m}$, respectively, and were altered according to the discretion of the surgeon who made adjustments in the laser parameters intraoperatively. Table 1 shows the femtosecond laser parameters that were used.

The lens fragmentation pattern comprised a 2-mm central cylinder combined with two 4.8-mm chops. There were two energy protocols for lens fragmentation: 1) the standard protocol, in which $8 \mu$ w was applied to the anterior $2 \mathrm{~mm}$ of the lens and $7 \mu$ w was applied to the posterior $3 \mathrm{~mm}$ of the lens and 2) the dense cataract protocol, in which $11.50 \mu$ J was applied to the anterior $2 \mathrm{~mm}$ of the lens and $9.50 \mu$ J was applied to the posterior $3 \mathrm{~mm}$ of the lens. We routinely used the dense cataract protocol on eyes that had a nuclear opalescence $\geq 3$ in the Lens Opacity Classification System III $^{(17)}$.

After the laser pretreatment and before starting phacoemulsification, we routinely checked the patient's pupillary status. The re-dilation technique was applied on eyes that evolved with a pupillary diameter that was
Table 1. Parameters for femtosecond laser pretreatment ( $n=75$ eyes)

\begin{tabular}{|c|c|}
\hline Parameters & Values \\
\hline \multicolumn{2}{|l|}{ Primary incision } \\
\hline Pulse energy $(\mu))$ & 5 \\
\hline Spot/layer separation $(\mu \mathrm{m})$ & $3 / 3$ \\
\hline Arc diameter (mm) & 16 \\
\hline Width/Trapezoid offset (mm) & 2.7/0.1 internal \\
\hline \multicolumn{2}{|l|}{ Side-port incision } \\
\hline Pulse energy $(\mu \mathrm{J})$ & 5 \\
\hline Spot/layer separation $(\mu \mathrm{m})$ & $4 / 3$ \\
\hline Arc diameter (mm) & 16 \\
\hline Width/Trapezoid offset (mm) & 1.1/0.1 internal \\
\hline \multicolumn{2}{|l|}{ Arcuate incision } \\
\hline Diameter (mm) & 90 \\
\hline$\%$ posterior depth & 85 \\
\hline Side cut angle (degree) & 90 \\
\hline Pulse energy $(\mu \mathrm{J})$ & 2.4 \\
\hline Spot/layer separation $(\mu \mathrm{m})$ & $4 / 4$ \\
\hline \multicolumn{2}{|l|}{ Capsulotomy } \\
\hline Diameter (mm) & 4.9 \\
\hline Pulse energy $(\mu \mathrm{J})$ & $6.0-7.5$ \\
\hline Tangential spot/layer separation $(\mu \mathrm{m})$ & $5 / 5$ \\
\hline Delta up/down $(\mu \mathrm{m})$ & $275 / 350$ \\
\hline \multicolumn{2}{|l|}{ Lens fragmentation } \\
\hline Diameter (mm) & 4.7 \\
\hline Standard protocol pulse energy & $\begin{array}{c}8 \mu \mathrm{J} \text { to the anterior } 2 \mathrm{~mm} \text { of } \\
\text { the lens } / 7 \mu \text { ) to the posterior } \\
3 \mathrm{~mm} \text { of the lens }\end{array}$ \\
\hline Dense cataract protocol pulse energy & $\begin{array}{l}11.50 \mu \text { ) to the anterior } 2 \mathrm{~mm} \\
\text { of the lens } / 9.50 \mu \text { to the } \\
\text { posterior } 3 \mathrm{~mm} \text { of the lens }\end{array}$ \\
\hline Anterior/posterior offset $(\mu \mathrm{m})$ & $500 / 800$ \\
\hline Spot/layer separation $(\mu \mathrm{m})$ & $10 / 10$ \\
\hline
\end{tabular}

smaller than the programmed capsulotomy diameter, which hindered identification of the capsulotomy's borders ${ }^{(16)}$. This technique consisted of re-dilating the pupil using $1 \%$ tropicamide and $10 \%$ phenylephrine every 10 minutes for 30 minutes before proceeding with phacoemulsification.

The surgical videos of both the femtosecond laser pretreatment and the phacoemulsification of all patients were reviewed. Two images were captured for each eye, one immediately after turning on the suction of the femtosecond laser at the start of the pretreatment and another under the surgical microscope, immediately before opening the incisions to start the phacoemulsification. These images were used to calculate the pupillary and capsulotomy diameter and area using the Image] 
software (National Institute of Health) (Figure 1)(A). Pupillary diameter was assessed based on its maximum horizontal dimension. On the two video images that were obtained, we used our routine programmed capsulotomy diameter of $4.9 \mathrm{~mm}$ to determine the pupillary diameter and area, based on the following formulae:

Pupillary area $\left(\mathrm{mm}^{2}\right)=$ (pupillary area on video/capsulotomy area on video) $\times \pi \times(\text { programmed capsulotomy diameter } / 2)^{2}$

Pupillary diameter $(\mathrm{mm})=$ (pupillary diameter on video/ capsulotomy diameter on video) $\times \pi \times$ (programmed capsulotomy diameter)

A pupillary diameter $<6 \mathrm{~mm}$ was considered small for cataract extraction, whereas $<5 \mathrm{~mm}$ was considered clinically significant for cataract extraction ${ }^{(7)}$.

In addition, the distance ( $\mathrm{mm}$ ) between the capsulotomy and pupillary borders was calculated as the pupillary diameter minus the capsulotomy diameter divided by 2 .

\section{Statistical analysis}

Statistical analyses were performed using SPSS for Windows (version 18.0, SPSS Inc., Chicago, Illinois, USA) and Microsoft Office Excel (Microsoft, Redmond,
Washington, USA). The results of the qualitative variables were expressed by their absolute and relative frequencies; whereas the results of the quantitative variables were expressed by their minimum and maximum values and mean and standard deviation (SD). The paired Student's $t$-test was used to compare the pupillary area and diameter before the laser pretreatment with those at the beginning of phacoemulsification. The Pearson correlation coefficient and the independent sample t-test were used to identify statistically significant correlations between the reduction in the pupillary diameter with the quantitative and qualitative variables, respectively. Normality was checked by the Kolmogorov-Smirnov test. A $p<0.05$ was used throughout this study to reject the null hypothesis.

\section{RESULTS}

The total number of FLACS done during the study period was 262, of which 133 were done in the room with a video recording system. Of these, 58 were excluded following the exclusion criteria. If the second operating room had a video recording system, 61 of the 129 eyes operated would have been excluded based on our exclusion criteria.
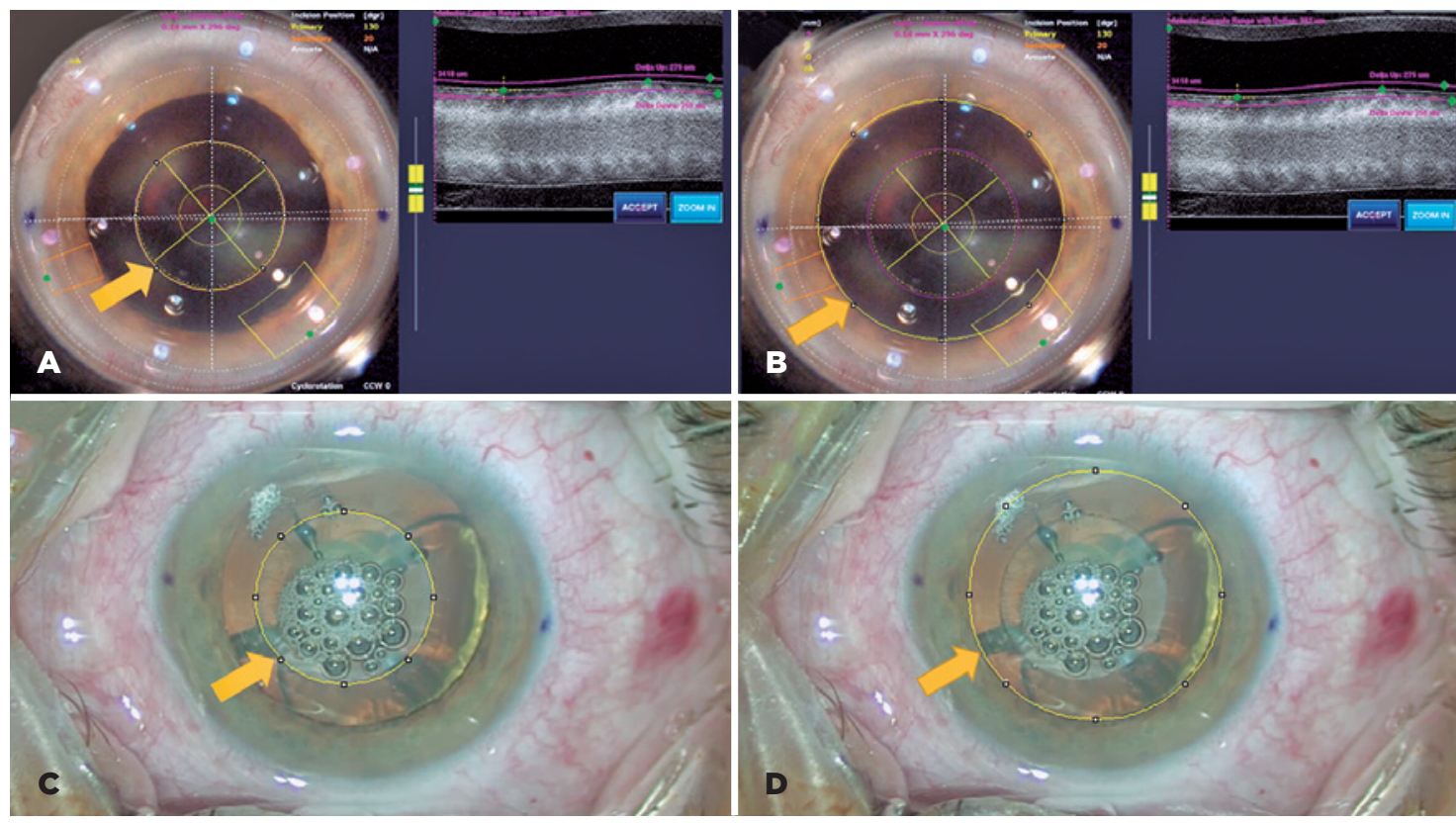

Figure 1. ImageJ software calculations. Screenshots of the femtosecond laser display immediately after turning the suction on show the capsulotomy border (A) and the pupillary border (B) demarcated by the yellow circle (yellow arrow) created by the ImageJ software. Screenshots of the surgical video immediately before opening the incisions to the start phacoemulsification show the capsulotomy border (C) and the pupillary border (D) demarcated by the yellow circle (yellow arrow) created by the ImageJ software. 
Finally, 75 eyes of 70 patients were analyzed in this study. The participants' mean age was $69.3 \pm 7.9$ years (range, 50-90 years); 49 (70.0\%) were women; 38 (54.3\%) had hypertension; and 17 (24.3\%) had diabetes mellitus. The patients' preoperative and femtosecond laser data are shown in table 2 . Nine (12\%) eyes evolved with a pupillary diameter that was smaller than the programmed capsulotomy diameter after the laser pretreatment and before moving the patient into the operating room for phacoemulsification. In these eyes, the re-dilation technique was applied before proceeding with cataract extraction.

Table 3 shows the pupillary diameter and area of all the eyes before the laser pretreatment and immediately

Table 2. Patients' preoperative and femtosecond laser data ( $n=75$ eyes)

\begin{tabular}{|c|c|}
\hline Parameter & Mean \pm SD (Range) \\
\hline IOP (mmHg) & $\begin{array}{c}16.6 \pm 3.5 \\
(9-24)\end{array}$ \\
\hline Endothelial cell count (cells $/ \mathrm{mm}^{3}$ ) & $\begin{array}{c}2367.6 \pm 331.1 \\
(1309-3004)\end{array}$ \\
\hline Central corneal thickness $(\mu \mathrm{m})$ & $\begin{array}{c}525.1 \pm 29.5 \\
(447-591)\end{array}$ \\
\hline Suction-on time (seconds) & $\begin{array}{c}151.5 \pm 33.7 \\
(64-249)\end{array}$ \\
\hline Lens thickness ( $\mu \mathrm{m})$ & $\begin{array}{c}3816.5 \pm 369.8 \\
(2932-4515)\end{array}$ \\
\hline Distance between delta up and delta down $(\mu \mathrm{m})$ & $\begin{array}{c}635.4 \pm 38.6 \\
(600-745)\end{array}$ \\
\hline \multicolumn{2}{|l|}{ Arcuate incision, $\mathrm{N}(\%)$} \\
\hline Performed & $16(21.3)$ \\
\hline Not performed & $59(78.7)$ \\
\hline \multicolumn{2}{|l|}{ Energy for capsulotomy confection, N (\%) } \\
\hline $6.0 \mu \mathrm{J}$ & $30(4.0)$ \\
\hline $6.5 \mu \mathrm{J}$ & $40(5.3)$ \\
\hline $7.0 \mu \mathrm{J}$ & $40(53.3)$ \\
\hline $7.5 \mu \mathrm{J}$ & $28(37.3)$ \\
\hline \multicolumn{2}{|l|}{ Lens fragmentation, $\mathrm{N}(\%)$} \\
\hline Standard protocol & $16(21.3)$ \\
\hline Hard protocol & $59(78.7)$ \\
\hline
\end{tabular}

$\mathrm{SD}=$ standard deviation; $\mathrm{IOP}=$ intraocular pressure.

Table 3. Pupillary diameter and area during femtosecond laser-assisted cataract surgery ( $n=75$ eyes)

\begin{tabular}{|c|c|c|c|}
\hline Parameters & $\begin{array}{l}\text { Before femtosecond } \\
\text { laser pretreatment } \\
\text { Mean } \pm S D \text { (range) }\end{array}$ & $\begin{array}{l}\text { Immediately before } \\
\text { phacoemulsification } \\
\text { Mean } \pm \text { SD (range) }\end{array}$ & $P$ value \\
\hline $\begin{array}{l}\text { Pupillary } \\
\text { diameter (mm) }\end{array}$ & $\begin{array}{l}6.9 \pm 0.5 \\
(5.7-8.3)\end{array}$ & $\begin{array}{l}6.8 \pm 0.7 \\
(5.2-8.9)\end{array}$ & 0.412 \\
\hline $\begin{array}{l}\text { Pupillary area } \\
\left(\mathrm{mm}^{2}\right)\end{array}$ & $\begin{array}{l}37.0 \pm 5.8 \\
(26.4-54.1)\end{array}$ & $\begin{array}{l}36.1 \pm 7.6 \\
(20.5-59.3)\end{array}$ & 0.437 \\
\hline
\end{tabular}

$\mathrm{SD}=$ standard deviation. before opening the wounds for phacoemulsification. The mean pupillary diameter and area did not significantly differ between these two surgical time points $(p=0.412$ and 0.437 , respectively), even in the subgroup comparison between eyes that did not need the re-dilation and those in which the technique was used. The mean pupillary diameter before laser application and before phacoemulsification in the first subgroup was $6.9 \pm 0.6 \mathrm{~mm}$ and $6.9 \pm 0.7 \mathrm{~mm}$, respectively, $(p=0.4)$ and the mean pupillary area was $37.2 \pm 6.0 \mathrm{~mm}^{2}$ and $37.1 \pm$ $7.2 \mathrm{~mm}^{2}$, respectively $(\mathrm{p}=0.5)$; a similar comparison in the second subgroup showed a mean pupillary diameter of $6.8 \pm 0.5 \mathrm{~mm}$ and $6.4 \pm 0.8 \mathrm{~mm}$, respectively $(\mathrm{p}=0.1)$ and a mean pupillary area of $35.8 \pm 5.3 \mathrm{~mm}^{2}$ and 31.9 $\pm 7.9 \mathrm{~mm}^{2}$, respectively $(p=0.1)$. Both subgroups had statistically similar mean pupillary diameter $(p=0.2)$ and area $(p=0.3)$ before femtosecond laser application, but they differed at the beginning of phacoemulsification with regard to both parameters $(p=0.024$ and 0.025 , respectively).

When analyzing all eyes, the overall pupillary area constriction was $2.4 \mathrm{~mm}^{2}$. The mean distance between the capsulotomy and the pupillary border did not significantly differ before femtosecond laser application and at the beginning of phacoemulsification $[1.0 \pm 0.3 \mathrm{~mm}$ (range, 0.4-1.7 mm) vs. $1.0 \pm 0.4 \mathrm{~mm}$ (range, 0.1-2.0 mm), respectively; $p=0.219]$. Immediately before opening the wounds for phacoemulsification, none of the eyes presented with a pupillary diameter $<5 \mathrm{~mm}$, and 64 (85.3\%) eyes had a pupillary diameter $>6 \mathrm{~mm}$. Table 4 shows the distribution of eyes with regard to pupillary diameter before the laser pretreatment and immediately before opening the wounds for phacoemulsification. None of the analyzed variables correlated with reduction in pupillary diameter when comparing the measurements made before the laser application with those at the beginning of phacoemulsification (Table 5).

\section{DISCUSSION}

Miosis secondary to femtosecond laser pretreatment in cataract surgery imposes surgical challenges. Mecha-

Table 4. Distribution of eyes according to the pupillary diameter during femtosecond laser-assisted cataract surgery ( $n=75$ eyes)

\begin{tabular}{lcc}
\hline Pupillary diameter & $\begin{array}{c}\text { Before femtosecond } \\
\text { laser pretreatment } \\
\mathbf{N}(\%)\end{array}$ & $\begin{array}{c}\text { Immediately before } \\
\text { phacoemulsification } \\
\mathbf{N}(\%)\end{array}$ \\
\hline$<5 \mathrm{~mm}$ & 0 & 0 \\
$5-6 \mathrm{~mm}$ & $3(4.0)$ & $11(14.7)$ \\
$>6 \mathrm{~mm}$ & $72(96.0)$ & $64(85.3)$ \\
\hline
\end{tabular}




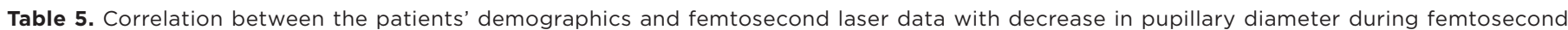
laser-assisted cataract surgery

\begin{tabular}{|c|c|c|}
\hline Parameter & $r$ value* $^{*}$ & $P$ value \\
\hline Age & -0.038 & 0.746 \\
\hline Hypertension & NA & 0.921 \\
\hline Diabetes mellitus & NA & 0.106 \\
\hline IOP & 0.097 & 0.407 \\
\hline Endothelial cell count & 0.091 & 0.436 \\
\hline Central corneal thickness & 0.087 & 0.458 \\
\hline Suction-on time & 0.094 & 0.421 \\
\hline Lens thickness & -0.001 & 0.992 \\
\hline Distance between delta up and delta down & -0.071 & 0.544 \\
\hline Distance between the capsulotomy and pupillary borders before femtosecond laser treatment & 0.123 & 0.293 \\
\hline Arcuate incision confection & NA & 0.759 \\
\hline Energy for primary incision confection & NA & 0.524 \\
\hline Lens fragmentation protocol & NA & 0.832 \\
\hline
\end{tabular}

$\mathrm{IOP}=$ intraocular pressure; $\mathrm{NA}=$ not applicable.

* Pearson correlation analysis was used in all evaluations, except for hypertension and diabetes mellitus history, arcuate incision confection, energy for primary incision confection, and lens fragmentation protocol, for which Spearman correlation analysis was used.

nical dilation devices, such as iris retractors and Malyugin ring (Microsurgical Technology, Redmond, WA), can be used to manage the constricted pupil ${ }^{(18)}$. However, since the capsulotomy has already been done by the laser and the small pupil hinders the visualization of the capsulotomy's edge, the insertion and positioning of these devices can cause capsular damage and further complications. We have recently published the re-dilation technique as an alternate solution for these cases ${ }^{(16)}$, with the goal of obtaining a second dilation that is bigger than the anterior capsulotomy's edge, allowing sufficient visualization as if the miosis had not occurred. In the present study, we assessed the pupillary size before laser pretreatment and at the beginning of phacoemulsification in eyes that received NSAID preoperatively and underwent the re-dilation technique if the pupillary diameter was $<4.9 \mathrm{~mm}$ after laser application.

There were no significant differences in the mean pupillary diameter, pupillary area, and distance between the capsulotomy and the pupillary border before the laser pretreatment and immediately before opening the wounds for phacoemulsification. These results are in contrast with those of previous studies ${ }^{(7,8)}$. Diakonis et al. ${ }^{(7)}$ reported a statistically significant decrease of $1.42 \mathrm{~mm}$ in mean pupillary diameter when using the LenSx. Although that study and ours included eyes that underwent FLACS with the LenSx and were pretreated with NSAIDs, our different results were probably from the variation in the pupil-dilating regimen and the application of the re-dilation technique in $12 \%$ of our eyes before proceeding with phacoemulsification.

The $12 \%$ incidence of clinically significant miosis before cataract extraction after femtosecond laser pretreatment was similar to that described by some authors ${ }^{(19)}$, but other studies reported incidences as high as $32 \%{ }^{(4)}$ and as low as $1.23 \%^{(5)}$. The fact that none of the eyes in this study started phacoemulsification with a pupillary diameter $<5 \mathrm{~mm}$, despite the $12 \%$ incidence of secondary miosis, implies the effectiveness of the re-dilation technique in reversing laser-induced pupillary constriction in eyes that were pretreated with NSAIDs. This approach allows a satisfactory pupillary diameter for cataract extraction and discards the need to use iris retractors or iris expansion rings.

The effectiveness of our approach is also seen when comparing the percentage of eyes with a pupillary diameter $<5 \mathrm{~mm}$, between 5 and $6 \mathrm{~mm}$, and $>6 \mathrm{~mm}$ immediately before starting phacoemulsification in FLACS. In a previous paper, the pupillary diameter was $<5 \mathrm{~mm}$ in $7.6 \%$ of the eyes after laser pre-treatment and before starting cataract extraction and $>6 \mathrm{~mm}$ in only $58.2 \%$ of the eyes ${ }^{(7)}$. On the other hand, in the present study, none of the eyes presented with a pupillary diameter $<5 \mathrm{~mm}$ immediately before phacoemulsification and $85.3 \%$ of the eyes had a pupillary diameter $>6 \mathrm{~mm}$. Therefore, while the surgeon proceeded with surgery with a 
clinically significant small pupil for cataract extraction in $7.6 \%$ of the eyes in the previous study ${ }^{(7)}$, increasing the risk of having further complications, this did not happen in any of the eyes included in our paper.

When comparing the measurement made before the laser application and immediately before phacoemulsification, the overall pupillary area constriction in our study was $2.4 \mathrm{~mm}^{2}$. This was in contrast with the results of Jun et al..$^{(8)}$, who reported a pupillary constriction of $29.7 \%$ from the initiation of femtosecond laser pretreatment with the Catalys Precision Laser System to the initiation of phacoemulsification. They did not use tropicamide and phenylephrine between the laser application and the phacoemulsification, preoperative NSAID, or the re-dilation technique. Furthermore, the different peculiarities among the femtosecond laser platforms in terms of the docking system, total time of laser application, and time and energy to perform each of the pretreatment steps probably had a varying impact on the pupil size during surgery ${ }^{(7)}$. However, we postulated the importance of preoperative NSAID and the re-dilation technique to achieve our results with the LenSx, since another paper has shown that this femtosecond laser platform induced a higher degree of miosis compared with that of the Catalys Precision Laser System ${ }^{(7)}$. Therefore, our data suggested that both the preoperative use of NSAID and the as-needed re-dilation technique were effective in minimizing pupil size variation, based on the comparison of mydriasis before laser pretreatment and at the beginning of phacoemulsification.

When comparing the two surgical time points in this study, none of the analyzed variables correlated with reduction in pupillary diameter in the eyes that received preoperative NSAID combined with the re-dilation technique, as necessary. This result differed from the findings of a previous study that reported a correlation of the degree of miosis with patient's age, time for lens fragmentation, and time for main incision creation, when assessing the Catalys Precision Laser System ${ }^{(8)}$. These different results were probably due to the variations in the dilating regimen, the combined approach of NSAID and the re-dilation technique, and the different femtosecond laser platforms used in each study.

The main limitations of our study include its retrospective nature and all the drawbacks associated with this design. We did not have a way to retrospectively measure the pupil size after femtosecond laser application and before moving the patient into the operating room for phacoemulsification. Therefore, we could not report the exact pupil size at this time point in the nine eyes that received the re-dilation technique. In addition, we did not have a record of the time lapse between the termination of the laser treatment and the assessment of the pupil size before proceeding with cataract extraction. Although a previous study did not find a higher degree of miosis with a longer time lapse between laser application and phacoemulsification, this would have been an interesting variable to evaluate ${ }^{(8)}$. Furthermore, some of the eyes that were operated on during the study period were not included in the analysis, because they were operated in a surgical room without a video recording system. Although inclusion of all eyes that were operated on would have been ideal, the cases were randomly assigned to each room, which reduces the potential for sampling bias.

In conclusion, the approach of preoperative NSAID use and the re-dilation technique, when necessary, was effective in minimizing pupil size variation before the laser pretreatment and at the beginning of phacoemulsification. No significant difference in pupil size was seen when comparing these two surgical time points. This approach avoided the need to proceed with phacoemulsification with a constricted pupil and the need to use iris retractors or expansion rings. Furthermore, it allowed a satisfactory pupillary diameter for the surgeons, in order to decrease the risk of complications during FLACS.

\section{REFERENCES}

1. Alio JL, Abdou AA, Puente AA, Zato MA, Nagy Z. Femtosecond laser cataract surgery: updates on technologies and outcomes. J Refract Surg. 2014;30(6):420-7.

2. Hatch KM, Schultz T, Talamo JH, Dick HB. Femtosecond laser-assisted compared with standard cataract surgery for removal of advanced cataracts. J Cataract Refract Surg. 2015;41(9):1833-8.

3. Crema AS, Walsh A, Yamane IS, Ventura BV, Santhiago MR. Femtosecond laser-assisted cataract surgery in patients with marfan syndrome and subluxated lens. J Refract Surg. 2015;31(5):338-41.

4. Nagy ZZ, Takacs Al, Filkorn T, Kránitz k, Gyenes A, Juhász É, et al. Complications of femtosecond laser-assisted cataract surgery. J Cataract Refract Surg. 2014;40(1):20-8.

5. Roberts TV, Lawless M, Bali S), Hodge C, Sutton G. Surgical outcomes and safety of femtosecond laser cataract surgery: a prospective study of 1500 consecutive cases. Ophthalmology. 2013;120(2):227-33.

6. Abell RG, Darian-Smith E, Kan JB, Allen PL, Ewe SY, Vote BJ. Femtosecond laser-assisted cataract surgery versus standard phacoemulsification cataract surgery: outcomes and safety in more than 4000 cases at a single center. J Cataract Refract Surg. 2015; 41(1):47-52.

7. Diakonis VF, Yesilirmak N, Sayed-Ahmed IO, Warren DP, Kounis GA, Davis Z, et al. Effects of femtosecond laser-assisted cataract pretreatment on pupil diameter: a comparison between three laser platforms. J Refract Surg. 2016;32(2):84-8. 
8. Jun JH, Hwang KY, Chang SD, Joo CK. Pupil-size alterations induced by photodisruption during femtosecond laser-assisted cataract surgery. J Cataract Refract Surg. 2015;41(2):278-85.

9. Artzen D, Lundstrom M, Behndig A, Stenevi U, Lydahl E, Montan P. Capsule complication during cataract surgery: case-control study of preoperative and intraoperative risk factors: Swedish Capsule Rupture Study Group report 2. J Cataract Refract Surg. 2009; 35(10):1688-93.

10. Cole DF, Unger WG. Prostaglandins as mediators for the responses of the eye to trauma. Exp Eye Res. 1973;17(4):357-68.

11. Schultz T, Joachim SC, Kuehn M, Dick HB. Changes in prostaglandin levels in patients undergoing femtosecond laser-assisted cataract surgery. J Refract Surg. 2013;29(11):742-7.

12. Wang L, Zhang Z, Koch DD, Jia Y, Cao W, Zhang S. Anterior chamber interleukin 1beta, interleukin 6 and prostaglandin E2 in patients undergoing femtosecond laser-assisted cataract surgery. Br J Ophthalmol. 2016;100(4):579-82.

13. Schultz T, Joachim SC, Szuler M, Stellbogen M, Dick HB. NSAID pretreatment inhibits prostaglandin release in femtosecond laser-assisted cataract surgery. J Refract Surg. 2015;31(12):791-4.

14. Kiss HJ, Takacs Al, Kranitz K, Sandor GL, Toth G, Gilanyi B, et al. One-day use of preoperative topical nonsteroidal anti-inflammatory drug prevents intraoperative prostaglandin level elevation during femtosecond laser-assisted cataract surgery. Curr Eye Res. 2016;41(8):1064-7.
15. Diakonis VF, Kontadakis GA, Anagnostopoulos AG, Yesilirmak N, Waren DP, Cabot F, et al. Effects of short-term preoperative topical ketorolac on pupil diameter in eyes undergoing femtosecond laser-assisted capsulotomy. J Refract Surg. 2017;33(4):230-4.

16. Ventura BV, Ventura MC. Miosis secondary to femtosecond laser-assisted cataract surgery: redilation as a solution. J Refract Surg. 2016;32(4):281-2.

17. Chylack LT Jr., Wolfe JK, Singer DM, Leske MC, Bullimore MA, Bailey IL, et al. The lens opacities classification system Ill. The Longitudinal Study of Cataract Study Group. Arch Ophthalmol. 1993;111(6):831-6.

18. Dick HB, Schultz T. Laser-assisted cataract surgery in small pupils using mechanical dilation devices. J Refract Surg. 2013;29(12):858-62.

19. Bali SJ, Hodge C, Lawless M, Roberts TV, Sutton G. Early experience with the femtosecond laser for cataract surgery. Ophthalmology. 2012;119(5):891-9.

\section{OTHER CITED MATERIAL}

Rasband W. Image); Image processing and analysis in Java. Research Services Branch, Bethesda, MD: National Institutes of Health; 2014. [cited 2014 oct 24]. Available from: http://rsb.info.nih.gov/ij/. 